No. $44 \quad L=255^{\circ} \quad b=-18^{\circ}$.

Grosser behofter Fleck mit mehreren Kernen, veränderlich, und mit nachfolgenden kleinen Flecken; eingetreten Juni 17 .

No. $45 \quad L=25^{\circ}$ bis $247^{\circ} b=-25^{\circ}$.

Zuerst ein kleiner Fleck Juni 17 und I $\$$, dann einige Flecke 19; darauf Juni 20 Bildung einer bedeutenden Gruppe unter beträchlichen Aenderungen im Laufe dieses Tages und an den folgenden Tagren. Juni 24 und 25 waren die beiden Gruppen No. 44 und 45 so vergrössert dass sie eine einzige dicht mit Flecken besetzte Gruppe bildeten.

No. 47

$$
L=233^{\circ}
$$

$b=+14^{\circ} \mathrm{u} .+2 \mathrm{I}^{\circ}$.

Kleine Flecke, nur Juni 24 bis 26 beobachtet.

No. $49 \quad L=187^{\circ} \quad b=-17^{\circ}$.

Behofter Fleck, auf der Mitte der Sonnenscheibe entstanden; Juli 4 am SW-Rande.

No. $48 \quad L=133^{\circ} \quad b=\ldots 26^{\circ}$.

Fleck, eingetreten Juni 26 , von Juli I verschwunden.

No. $50 \quad L=126^{\circ}$ bis I I $4^{\circ} b=-37^{\circ}$.

Gruppe von wenigen Flecken.

No. $5 \mathrm{I} \quad L=70^{\circ} \quad b=-20^{\circ}$.

Gruppe, entstanden Juli 4 ; zahlreich Juli 6 bis 9 , darauf schnell vermindert.

No. $52 \quad L=42^{\circ} \quad b=-22^{\circ}$.

Kleiner Fleck, nur Juli i I beobachtet.

Rotationsperiode 264 . von of Juli 12 bis of Aug. 7.

No. $53 \quad L=332^{\circ} \quad b=-19^{\circ}$.

Kleine Flecke, beobachtet Juli 10 und 12 .
Daraut wurde die Sonne fleckenfrei gefunden an den Tagen Juli 13, 14, $15,16$.

No. $54 \quad L=284^{\circ} \quad b=+22^{\circ}$.

Kleine Flecke, nur Juli I 7 beobachtet.

No. $55 \cdot L=262^{\circ} \quad b=+22^{\circ}$.

Gruppe kleiner Flecke, erst Juli 2 I im nordwestlichen Quadranten entstanden.

No. $56 \quad L=243^{\circ}$ bis $227^{\circ} b=+21^{\circ}$.

Zuerst Juli 17. ein kleiner Fleck, bis Juli I9 noch unbedeutend, darauf schnelle Entwicklung einer zahlreichen Gruppe.

No. $57 \quad L=110^{\circ} \quad b=+25^{\circ}$.

Kleine Flecke Juli 25-3I; verschwunden Aug. I.

No. $58 \quad L=90^{\circ} \quad b=+13^{\circ}$.

Kleine Gruppe, nur Juli 28 und 29 beobachtet.

No. $59 \quad L=90^{\circ} \quad b=+38^{\circ}$.

Kleiner Fleck, nur Aug. 4. im nordw. Quadr. beob

No. $60 \quad L=59^{\circ} \quad b=-16^{\circ}$.

Zwei kleine Flecke nahe dem Westrande Aug. 8.

No. 6I $L=17^{\circ}$ bis $3^{\circ} b=+12^{\circ}$.

Gruppe mit grossem behoften Fleck und anderen behoften Theilen, eingetreten Aug. I ; zuletzt beob. am westlichen Rande Aug. I 3.

No. $62 \quad L=17^{\circ} \quad b=-22^{\circ}$.

Kleine Flecke, beobachtet Aug. 6-8.

Potsdam 1881, April 26.

Prof. Dr. Spoever.

\title{
Schreiben des Herrn Professor Edw. C. Pickering an den Heransgeber.
}

Herewith I send you a list of objects discovered here, and having some peculiarity either of color or of the distribution of light in their spectra. The columns of the list contain successively a number for reference, the designations of the objects, their places for 1880 , the general character of their spectra, and additional remarks. In the column of designations, U. A. denotes the Uranometria Argentina, and is followed in each case by the constellation and number of the star in that work. All the stars described in it as red, and visible in this latitude, are in course of spectroscopic examination here, and those wich have thus far been noted as remarkable are included in the present list. The other objects in the list were found during an extensive search for interesting stellar or nebulous spectra which is still going on at this Observatory.
Stars having interrupted spectra have been variously classified, but are generally said to be either of Type III or of Type IV. For a satisfactory classification, measures are requisite, and have heen undertaken here, which will show the forms of light curve exhibited by interrupted spectra of different kinds. In the present list, the term » Type III is applied only to continuous spectra divided by several narrow bands, and resembling those of $a$ Herculis and $a$ Orinis. "Type" IV denotes what may be regarded as the normal fourth type. A spectrum thus described consists of a well defined yellow band, a broad green band well defined on the more refrangible side and generally less sharply bounded on the other, and a blue band, in some cases well defined towards the violet. Interrupted spectra which could not be assigned to either class with con- 
fidence, or at least without much doubt, have been interrogation point in the column of spectra.

described in the list by the word »bands " or »bright lines ; when more detail seemed to be desirable, it is added in the column of remarks. Some doubt with regard to the spectrum of a star is indicated by an

The list contains thirty-three stars with peculiar spectra, three remarkable only for their redness, and three small planetary nebulae.

Objects remarkable for their colors or spectra, found at the Astronomical Observatory of Harvard College.

\begin{tabular}{|c|c|c|c|c|c|}
\hline No & Designation & R. A., 1880 & Decl., 1880 & Spectrum & $\mathrm{R}$ e $\mathrm{m} \mathrm{a} \mathrm{rks}$ \\
\hline I & U. A., Cetus, 13 & $0^{\mathrm{h}} \quad 2^{\mathrm{m}} 25^{\mathrm{s}}$ & $-18^{\circ} \mathrm{I} 4^{\circ} 6$ & Type III? & \\
\hline 2 & U. A., Cetus, 22 & 08 i9 & -826.8 & Type III & \\
\hline 3 & U. A., Cetus, 25 & $0 \quad 832$ & -1935.8 & Type III & \\
\hline 4 & U. A., Pisces, 80 & $\begin{array}{lll}0 & 14 & 0\end{array}$ & $+\quad 222.1$ & Bands. & Perhaps variable; red. \\
\hline 5 & $R$ Piscium & I $24 \quad 27$ & $+\quad 215.6$ & Type IV? & Bands distinct; fine specimen. \\
\hline 6 & DM. $+30^{\circ} 310$ & I $5 \mathrm{I} 9$ & +3033.0 & Bands. & \\
\hline 7 & DM. + $54^{\prime \prime} 43$ I & I 5137 & +5414.4 & Bands. & $\begin{array}{l}\text { Broad well marked bands; star red. Found } \\
\text { by O. C. Wendell. }\end{array}$ \\
\hline 8 & U. A. Cetus, 196 & I 548 & -2124.4 & Type III & \\
\hline 9 & $\mathrm{DN}+56^{\prime \prime} 724$ & 24118 & +5628.9 & Bands. & Star red.; bands suspected. \\
\hline 10 & DM. $+57^{\circ} 702$ & $3 \quad 2 \quad \mathrm{I} 2$ & +5726.7 & Type IV & Fine specimen. \\
\hline II & U. A., Fornax, 83 & $3 \quad 1421$ & -2433.5 & Type III & \\
\hline 12 & U. A., Ericlanus, 127 & $340 \quad 22$ & -1228.0 & Type III & \\
\hline I 3 & & $350 \quad 53$ & -1357 & Bands. & Star $s p \gamma$ Eridani. \\
\hline 14 & U. A., Caelum, I 2 & $4 \quad 38 \quad 32$ & -3059.3 & Type III? & Found by A. Searle. \\
\hline 15 & DM. $+6^{0} 810$ & 45520 & +628.4 & Bands. & Broad bright band in red., narrow one in green. \\
\hline 16 & DM. $+7: 103$ & 55640 & +737.5 & & $\begin{array}{l}\text { Spectrum continious, with much red, in contrast } \\
\text { with DM. }+7^{0} \text { I099, when the red is feeble. }\end{array}$ \\
\hline 17 & U. A., Lepus, 9 r & 6153 & -2148.9 & Type III & Red. \\
\hline 18 & U. A., Lepus, 92 & $\begin{array}{lll}6 & 2 & 29\end{array}$ & - I9 19.2 & Type III? & Red. \\
\hline 19 & U. A., Can. Maj. $16 \frac{1}{2}$ & 6 I 530 & - II 45.8 & Type III? & \\
\hline 20 & U. A., Can. Maj., 38 & 62458 & -198.1 & Type inl? & \\
\hline $2 \mathrm{I}$ & & $63^{8} 17$ & +326.8 & Type IV & Very red.: magnitude Ir. \\
\hline 22 & Lalande 13412 & 649 I 3 & --2346.5 & Bright lines. & Wave-lengths $545,486,(\mathrm{~F}), 467$. \\
\hline 23 & U. A., Puppis, 73 & 7953 & -4426.7 & Bands. & \\
\hline 24 & U. A., Can. Maj., I47 & 7 I I 46 & -2740.2 & Bands. & Found by A. Searle. \\
\hline $\begin{array}{l}25 \\
26\end{array}$ & & 755514 & -1231 & Bands & \\
\hline & U. A., Puppis, $25 \mathrm{I}$ & $\begin{array}{rrr}7 & 50 & 34 \\
8 & 1 & 7\end{array}$ & $\begin{array}{l}-1242 \\
-3313.6\end{array}$ & $\begin{array}{l}\text { Type iV } \\
\text { Bands. }\end{array}$ & Found by $\mathrm{O}$. C. Wendell. \\
\hline 28 & U. A., Hydra, 58 & 84021 & -1034.3 & Type III & Found by $\mathrm{O}$. $\mathrm{C}$. Wendell. \\
\hline 29 & U. A, Pyxis, 34 & $845 \quad I$ & -291.0 & Type IV & Found by $O$. C. Wendell. \\
\hline 30 & U. A, Antlia, 7I & 102953 & -3856.5 & Type IV & Red. \\
\hline 31 & Oeltzen 17681 & $18 \quad 1 \quad 17$ & -2116.0 & Bright lines. & Wave-iengths $580,467$. \\
\hline 32 & Planetary nebula & 18419 & $-28 \mathrm{i} 2$ & Gascous & \\
\hline 33 & > & $18 \quad 1423$ & -2653 & Gaseous & Faint and small. \\
\hline 34 & 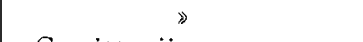 & I8 $25 \quad 10$ & -2513 & Gascous & Bright and small. \\
\hline 35 & c Sagittarii & 195516 & $\begin{array}{ll}-28 & 2.7\end{array}$ & Type III & \\
\hline 36 & & $20 \quad 4 \quad 32$ & +3528 & Type IV & Very red. \\
\hline 37 & & $20 \quad 4 \quad 37$ & +3533 & & Color strong red.; spectrum not peculiar. \\
\hline 38 & & $20 \quad 6 \quad 34$ & +3544 & Type IV & Red. \\
\hline 39 & & $23 \quad 5257$ & +6213 & & $\begin{array}{l}\text { Red; spectrum not peculiar, found by } \mathrm{O} . \mathrm{C} \text {. } \\
\text { Wendell. }\end{array}$ \\
\hline
\end{tabular}

Harvard College Observatory, Cambridge, U. S. April I8, i 188 I. 